\title{
Rule of Law and Its Guidelines and Indicators for Judiciary in Human Rights Issues
}

\author{
Ebad Rouhi ${ }^{1}$, Leila Raisi Dezaki ${ }^{1} \&$ Mahmoud Jalali Karveh ${ }^{2}$ \\ ${ }^{1}$ Department of Law, Isfahan (Khorasgan) Branch, Islamic Azad University, Isfahan, Iran \\ ${ }^{2}$ Law Department, University of Isfahan, Isfahan, Iran \\ Correspondence: Leila Raisi Dezaki, Department of Law, Isfahan (Khorasgan) Branch, Islamic Azad University, \\ Isfahan, Iran.
}

Received: September 4, $2016 \quad$ Accepted: October 2, $2016 \quad$ Online Published: December 29, 2016
$\begin{aligned} & \text { doi:10.5539/jpl.v10n1p98 } \\ & \text { URL: http://dx.doi.org/10.5539/jpl.v10n1p98 }\end{aligned}$

\begin{abstract}
The rule of law is one of the very polemical and controversial concepts in the field of public law and political thoughts. This concept has been acclaimed in both international and domestic level and can be observed in the practice of the United Nations and many of states practically. In the light of the principle of the rule of law at the meantime ruling by law can be strengthened and also security and peace, development, democracy and human rights can be protected and promoted. The rule of law and human rights as two concepts with mutually interacting to each other has noteworthy great importance. An independent and impartial judiciary such as linkage has an important role in strengthening both of them.

Human rights, separation of powers and judicial independence are regarded as some basis of the rule of law and as well as its consequence. Thus, in this regard rule of law has $p$ very guidelines and indicators which some of them related to the judicial systems of states. In the light of exercise of these guidelines human rights are better protected and promoted.

These instructions and guidelines generally are provided in international and regional human rights instruments to enforce in every sector of the state and especially for judges and judicial power to protection and promotion of human rights. This article investigates the relationship between rule of law and judicial system to introduce some measures and indicators of the rule of law to enforce them in the judiciary for better protection and promotion of human rights.
\end{abstract}

Keywords: rule of law, judicial independence, rule of law indicators, human rights

\section{Introduction}

To realize justice and prevent the abuse and violation of rights, the theorists of philosophy of law and political thought refer to the theory of rule of law and believe that through the rule of law, a dynamic, sustainable and spirited and vivid society can be created in which the law dominates every action, individuals and institutions. Despite of polemical and controversial nature of the rule of law, all of the philosophers and lawyers support this theory that this law should dominate every aspect of a society. But each one of them explained the rule of law and offered their distinctive perception of the rule of law based on their ideas and the essence, content and conditions of their surrounding legal and political system. The different conceptions of rule of rule led to different laws and behaviors in every society from the legal, political and judicial viewpoints.

The historical and philosophical evolution of the legal and philosophical thought, as well as international law and the international human rights system shows that the trend toward the rule of law and supremacy of law over the structures and individuals have an incremental trend and the number of UN General Assembly resolutions on the rule of law manifests the significance of this issue more clearly. Among all conceptions and viewpoints of the rule of law, one could point to two dominant trends, each of which promotes a different and significant conception of the rule of law and originate the two schools of natural rights and legal positivism. These two dominant conceptions and viewpoints offer distinctive items and elements for the rule of law and refer to different principles of the theory of rule of law. Each one of both conceptions unexceptionally deals with the role of the judicial system and independence of this system in stabilization and application of the rule of law. They regard the rule of law to be impossible without the existence of a judicial system. These conceptions are referred 
to as the formal and substantive conceptions of rule of law. Different criteria have been developed in regard to the independence of the judicial system and its regulative and controlling role in association to the actions of citizens and behavior and decisions of the authorities. The independence of the judicial system and its users depends on the competency that the system has in realization of justice.

Both of these conceptions have some guidelines and indicators for judiciary to make it efficient and independent from other powers. These guidelines are so significant and important for judicial systems and administration of justice, especially in criminal justice, which exercising them led to impartiality and independence of judiciary and consequently protection and promotion of human rights.

To study this subject firstly the different conceptions of rule of law are investigated and then the mutual relationship between the rule of law and judicial independence is analyzed and in respect of protection and promotion of human rights continuing this matter with discussing and introducing the rule of law's guidelines and indicators which related to judicial systems.

\section{Concept of Rule of Law and Its Different Attitudes}

Rule of law in some form may be traced back to Aristotle, and has been championed by Roman jurists; medieval natural law thinkers; Enlightenment philosophers such as Hobbes, Locke, Rousseau, Montesquieu and the American founders; German philosophers Kant, Hegel, and the nineteenth century advocates of the Rechtsstaat; and in this century such ideologically diverse figures as Hayek, Rawls, Scalia, Jiang Zemin and Lee Kuan Yew. (Peerenbom, 2005: 1). Each one of these thinkers has a different approach to the rule of law and its principles and considers the different elements for it too. Some believe in the formal conception of the theory of rule of law and others believe in a substantive conception of it.

Identifying conditions necessary for a society to be said to be subject to the rule of law does not tell one much about the content of the society's laws, and there is widespread disagreement over exactly what that content must be. Some thinkers in the area focus on the existence of a structure and fair procedures for making and enforcing laws. Others focus more heavily on the content of the law itself. The two concerns are reflected by two views of the rule of law, a formalist one, which emphasizes the procedures for making and enforcing law and the structure of the nation's legal system, or a substantive one, in which certain rights are protected. Using the list of rule of law values described above, the transparency and stability of the law is more closely a formalist concern, while the protection of human rights and fundamental freedoms is a substantive one. While it is important to recognize that legal systems can be described both along formalist and substantive lines, the two are not mutually exclusive (for instance, protection against arbitrary state action). One can be committed to both formalist and substantive requirements for the rule of law. Indeed, it is difficult to find someone with a strong substantive approach to rule of law who would not also insist that the state in question follow certain procedures in making and enforcing law. Thus, one set of authors on the subject distinguish between "minimalist" approaches that may be merely formalist and "maximalist" approaches that include both formalist and relatively strong substantive components (Cole, 2011:9).

The rule of law has been described as a "significantly important concept not defined before and not easily definable". This is due to the diversity of elements and items of this concept which change in regard to different perspectives. The rule of law is a significant polemical idea for which one cannot find a shared framework among the experts that endeavored to define it (Markaz Malmiri, 2007:20). Despite its nearly universal appeal, rule of law, like human rights, is an essentially contested concept. It means different things to different people and has served a wide variety of political agendas from Hayekian libertarianism, to Rawlsian social welfare liberalism, to Lee Kuan Yew's soft authoritarianism, to Jiang Zemin's statist socialism, to a Sharia-based Islamic state. That is both its strength and its weakness. Those people of vastly different political persuasions, all want to take advantage of the rhetorical power of rule of law keeps it alive in public discourse, but it also leads to the worry that it has become a meaningless slogan devoid of any determinative content. At its most basic, rule of law refers to a system in which law is able to impose meaningful restraints on the state and individual members of the ruling elite, as captured in the rhetorically powerful, if overly simplistic, notions of a government of laws, the supremacy of the law and equality of all before the law (Peerenboom, 2005:18-19). Different formulations in regard to formal and substantive conceptions of the rule of law could be observed.

Minimum consensus as the condition of acknowledgement of the concept of rule of law can be framed in two propositions. First, the state should make rational decisions and act accordingly. This means that realization of decisions should be based on "reasons". Second, reasons in one of its significance should be legal too. These two abstract propositions are formal ones and as a result, they seem to be sufficiently non-polemical. The first proposition does not presume a certain type of government and does not suggest an objective entity of "state". In 
the same vein, the second proposition does not include a certain substance or content of "legal reasons" (Tremblay, 1997: 31).

One might regard the most famous and comprehensive written expression of the concept of the rule of law to be the explained concept of Albert Venn Dicey. It seems that from the viewpoint of most of the thinkers of the realm of the rule of law, Dicey is regarded as the reformer of "rule of law" (Markaz Malmiri, 2007: 28). Based on the Dicey's viewpoint, one could say that the rule of law is about the supremacy of law to human state and government. In other words, it refers to an absolute supremacy law to human. In addition, the equality of all individuals, despite of their political and social position as well as submission to legal authorities, is associated with the principle of rule of law (Rostam Nejad and Rahim Khoi, 2012: 15). In all of the associated theories, one could witness the existence of the concept of equality before the law, submission to law and its supremacy. In this regard, there is almost no difference among them. The differences are realized in content and essence which lead to distinctive perceptions of different elements of this concept.

In the formal conception of the rule of law, the compliance with the law and application of the principle of "legality" are regarded as the most important principles. However, in substantive conceptions of the rule of law, attention to other extralegal and ethical principles and standards such as the principles of natural law and principles of justice are significant and constitute an essential element of the theory of rule of law (Markaz Malmiri, 2007: 56). The first significant point in distinction of these two conceptions is the association of these conceptions with two categories of theories on the association between "legal fact" and "moral fact", namely the theories of "natural right" and theories of "legal positivism". The theories of legal positivism associate "legal argument" with external reality and merely consider something as "law" when it is announced as "law" by competent authorities. But the theories of natural rights regard the legal argument as equivalent with moral argument and consider real law to be the one which is compliant with the moral law (Rasekh, 2006:73-76). The positivists regard something with legal form, formally passed by competent authorities and going through the procedural process of legalization as law. They regard its realization and implementation as equivalent to rule of law. As a result, they do not concern themselves with just and moral content of law or basing the law on the principles and standards of human rights while naturalists pay more attention to the content of the legal system and essence of law. They consider the rule of law to be legitimate and legal when its compliance with fairness, equality, freedom, ethical values and human rights with legislated issue exists.

However, the advocates of both conceptions agree that the objective of the rule of law is limitation of state authorities in exercising their powers. Despite this agreement, each one of these approaches implements different instruments and means to obtain their objective. The formal conception of the rule of law lacks verdict in regard to the way of codification of law. In this regard, the significant issue is that the law is passed through competent authorities and satisfies the essential characteristics of law (Rasekh, 2006: 65). From this viewpoint, the necessary and sufficient conditions of regarding a text as law are complied with characteristics, formal and ritual conditions, as well as approval by a competent authority. Therefore, the implementation of such a bill or act is regarded as the rule of law from the viewpoint of advocates of formal conception. The advocates of substantive conception of the rule of law explain the rule of law from a perspective beyond legal positivism and with consideration of other fundamental values. In fact, this conception goes beyond a formal approach and necessitates the law to consider some substantive characteristics. The main characteristic of substantive conception is emphasis upon the dominant role of moral teachings codified in law.

In a substantive conception of the rule of law, constitutionalism is regarded as a part of the theory of the rule of law. The rule of law and the constitution have joint objectives the realization of which lead to support of human rights and its reinforcement. The framing and limitation of power, the establishment of democratic rule, guaranteeing rights and civil liberties as well as realization of justice are the common objectives of these two concepts. The exercise of freedoms is guaranteed only when they are codified as a set of personal rights in a charter of rights based on the constitution. The defense of rights and liberties is the necessary condition for realization of democracy which is only evaluable through the reference of courts to such a charter of rights. This idea had outstanding overlap with the idea of rule of law (Beetham, 2004: 62-63).

Despite of difference in the bases of their viewpoints, the advocates of both conceptions of formal and substantive conceptions follow similar objective in regard to law and its content and utilize their own means and methods so as to limit the power and options of state authorities, assign supremacy to what they identify as law and dominate it on all state authorities and figures as well as entities of power. Regardless of the content of the law that constitutes the argument between these two approaches, they both agree on the fact that one of the items of rule of law and a condition of its realization is the existence of an independent judicial system as a monitoring and controlling authority. Now, this entity that exercises surveillance of state actions and authorities should also 
follow the law. All of its figures and departments, from judge to officials and other practitioners should obey role. The judicial control as one of the elements of the rule of law has established its position in the legal-political systems. The effective punishment of official authorities such as suspension, dismissal and the obligation to recompense the damages that citizens undertake due to their decision or performance is one of the most significant means of the judiciary to apply the rule of law (Markaz Malmiri, 2007: 186).

The alignment of the judicial system with law implies the control of state officials, surveillance over them, and realization of the rights of citizens and parties of legal cases. The extent of independence of the judicial system and its alignment with formal and substantive criteria of rule of law, such as an Implementation of the law in the same conditions, independence and impartiality, and non-discrimination among the parties of trials represent the extent of realization of the rule of law. The judicial independence is an essential and inevitable element of the rule of law that plays a fundamental and critical role in the application of the rule of law (Montesquieu, 1748).

The United Nations in some documents tries to determine the Rule of Law. So, the definition below, articulated by the United Nations Secretary-General in a report to the Security Council in 2004, provides a foundation for the Rule of Law Indicators. It refers to a principle of governance in which all persons, institutions and entities, public and private, including the State itself, are accountable to laws that are publicly promulgated, equally enforced and independently adjudicated, and which are consistent with international human rights norms and standards. It requires, as well, measures to ensure adherence to the principles of supremacy of law, equality before the law, accountability to the law, fairness in the application of the law, separation of powers, participation in decision-making, legal certainty, avoidance of arbitrariness and procedural and legal transparency. (Report of the Secretary-General on the rule of law and transitional justice in conflict and post-conflict societies (S/2004/616), Para. 6.)

\section{The Relationship between Rule of Law and Judiciary}

Constitutionalism, ruled governmental affairs by law and an independent judiciary are elements of the rule of law which connected to each other. Although it seems that there is no problem for existence of these elements in the view of political regimes, but in practice they encounter with serious obstacles. Claims of constitution and an independent judiciary or governmental actions in accordance with the rule of law can exist in any political regime. The problems and obstacles are existed where the content of the constitution and applicable law is discussed and cannot be more expected of judiciary to monitor the implementation of laws contrary to the lessons of the substantive rule of law. In such circumstances, one may argue that there is the formal rule of law, but cannot claim that such ruling or such laws are legitimate. Perhaps claimed the legality, but is not expected legitimacy in such a situation. In other words, legality is not always meant to be legitimate and perhaps one law or an act has legality under the formal view, but in substantive perspective is unjust and illegitimate.

An indispensable requirement of the rule of law in each society is the presence of an impartial and independent judiciary, which, in the last resort, is able to resolve disputes and assure respect for the laws. In every society conflicts inevitably occur. Some of these conflicts arise in the relation between the government and the citizens. Other conflicts occur in the relations among citizens or other private entities. All of these conflicts must be resolved by law and under the rule of law. In this regard the United Nations Organizations provided many guidelines and indicators which some of them related to criminal justice and human rights.

If we believe that citizens have to obey the law, it must be the explicit interpretation of the law and how to apply its instances should also be apparent. Decision and verdict of a capacitated organ can bring such a clear understanding. Due to this we can say that the importance of the judiciary and its necessity are far beyond the institution as a dispute resolver. In fact, the judiciary helps the officials and citizens in general understanding and complying with the law.

An effect, consequence of the rule of law is the effective enforcement policies, means of monitoring and controlling the government in the financial sectors and reducing corruption in governmental and private sector. Transparency of laws and regulations related to financial institutions and the proper functioning of the company and fair and impartial enforcement of law by the courts, is a prerequisite in realizing these outcomes. Reliable performance, fair and honorable functions of courts have been led to economic prosperity and reduce corruption, but unfair and biased court performance can be increased corruption and lack of economic growth and prosperity and instead of being at the service of the realization of the rule of law, it is got the main obstacles for realizing and strengthening it. Thus the rule of law is the requirement of "good governance".

The role of the judiciary and judicial institutions is not limited to finance issues and vary widely, in cases related to human rights and ensure respect for these fundamental rights and basic freedoms play a crucial role in the judiciary and other governmental agencies. 


\section{Rule of Law's General Guidelines for Judicial System}

The rule of law in domestic law and international law has clear principles regarding the judiciary. This is especially in human rights issues and minimum sanctions for the rights of the accused and clear instructions in this regards is very clear. The rule of law has clear stance and guidelines for judicial independence, impartiality and fairness of the proceedings. Commitment to these issues is a part of fundamental human rights under the lessons of rule of law (Raz, 1977).

In both domestic and international law perspectives the rule of law has the same elements. So there is no difference between them under the substantive attitudes. But to some extent in according with the formal attitudes is variable. At both levels, it has the same guidelines and instructions. Some of indicators and guidelines have been provided by the United Nations Organization, which has to be considered in the legislature process. In order to be accommodated with rule of law, the laws must have the formal and substantive characteristics of law and also obey of international rule of law measures which separation of powers and judicial independence are two of them. Under the impartial and independence judiciary, human rights and legal rights are protected. Some of these measures are:

A. The law must be comprehensive

B. The law must be clear, certain and accessible

C. The law must be legitimate: consent and compliance
a) Legislative legitimacy
b) Legitimacy of policy
c) Legitimacy of application legitimacy of support structures

D. The law must balance stability and flexibility

E. Equality before law

F. Institutional independence and the separation of powers

G. Legal rights as element of the rule of law

The mentioned above are some of United Nations general guidelines about rule of law to enforce in national levels. These guidelines require that the judiciary must have the following characteristics:

Independence, Impartiality, Professional ethics, Freedom of expression and association, Qualifications, selection and training, Conditions of service and tenure, Professional secrecy and Immunity, Discipline, suspension and removal and also the courts must be accessible and procedures must be fair.

Some of the important and fundamental principles of judicial independence have been recognized by various legal systems and these principles have been emphasized in UN documents. Some of these principles are not directly related to judicial independence, but generally, in ensuring judicial independence is important. These principles are as follows:

\subsection{Independence}

Decisions of this kind must be made by a third party, a judge or a court of law. Those who belong to the judiciary must be free from outside pressures. They must decide according to the law and nothing but the law. This means, first of all, that they must be independent from the government. Their judgments must not be influenced by the powers that be. On the other hand, judges must commit to codes of professional integrity and conduct, and be accountable for judging in a fair manner. This independence must be promoted and ensured by laws regarding issues such as the appointment of judges, the security of tenure, conditions of service, and ways of setting salaries - all of which must be removed as far as possible from the government's influence. This matter reflected exactly in UN indicators for rule of law related to the judiciary. The Basic Principles on the Independence of the Judiciary, which adopted by the Seventh United Nations Congress on the Prevention of Crime and the Treatment of Offenders 1985 in Milan under the section of Independence of the judiciary provided that:

1) The independence of the judiciary shall be guaranteed by the State and enshrined in the Constitution or the law of the country. It is the duty of all governmental and other institutions to respect and observe the independence of the judiciary.

2) The judiciary shall decide matters before them impartially, on the basis of facts and in accordance with the law, without any restrictions, improper influences, inducements, pressures, threats or interferences, direct or indirect, from any quarter or for any reason. 
3) The judiciary shall have jurisdiction over all issues of a judicial nature and shall have exclusive authority to decide whether an issue submitted for its decision is within its competence as defined by law.

4) There shall not be any inappropriate or unwarranted interference with the judicial process, nor shall judicial decisions by the courts be subject to revision. This principle is without prejudice to judicial review or to mitigation or commutation by competent authorities of sentences imposed by the judiciary, in accordance with the law.

5) Everyone shall have the right to be tried by ordinary courts or tribunals using established legal procedures. Tribunals that do not use the duly established procedures of the legal process shall not be created to displace the jurisdiction belonging to the ordinary courts or judicial tribunals.

6) The principle of the independence of the judiciary entitles and requires the judiciary to ensure that judicial proceedings are conducted fairly and that the rights of the parties are respected.

7) It is the duty of each Member State to provide adequate resources to enable the judiciary to properly perform its functions.

"Basic Principles on the Independence of the Judiciary", Adopted by the Seventh United Nations Congress on the Prevention of Crime and the Treatment of Offenders held at Milan from 26 August to 6 September 1985 and endorsed by General Assembly resolution 40/32 of 29 November 1985 and 40/146 of 13 December 1985 .

\subsection{Impartiality}

A judge's freedom from outside pressures means, secondly, that the judge is impartial, in other words that he or she is not biased towards any of the parties in the case at hand. This requires, among other things, that party, if they have reason to suspect that the judge is biased, have an opportunity to challenge him or her. The result may be that the judge is taken off the case. Judges must also be entitled to recuse themselves in case they have a relationship with one of the parties to a conflict. One of the greatest threats to the impartiality and independence of the judiciary is corruption. For this reason, adequate salaries, security of tenure, and the likes are indispensable. That this must be balanced by obligations to observe codes of professional integrity and conduct appears from the above. This issue is reflected in the UN indicators for rule of law (The Raoul Wallenberg Institute of Human Rights and Humanitarian Law and the Hague Institute for the Internationalization of Law, 2012).

\subsection{Professional Ethics}

Applying the law correctly, equally for all, uninfluenced by outside pressure, does not only involve adequate rules and arrangements. It also involves high standards of professional ethics and good conduct among all participants in the dispute resolution process. Judges must also not compromise themselves in their private lives and jeopardize their independence and impartiality by making themselves susceptible to the pressure of outside influences. They must abide by the law, even in apparently trivial cases where many ordinary citizens may habitually have a tendency to disobey the law. Judges must even be cautious in engaging in activities which, though lawful, could possibly make them susceptible to outside pressure. It is very doubtful, for example, that judges should allow themselves to go gambling in perfectly lawful casinos. The same applies to prosecutors.

\subsection{Role of Politicians in Judicial Independence}

It is extremely important that politicians publicly accept and honor the independence and impartiality of the judiciary. Politicians must not, for example, give an opinion on what they consider to be the desirable outcome of a case which is before a court but has not yet been decided by the court. This could be interpreted by judges and the public at large - as outside pressure to influence the outcome of the case.

Politicians must also refrain from commenting on the details of outcomes of specific cases or suggest that cases have been decided wrongly. This does not mean, of course, that politicians can say nothing at all about case-law; they may wish to amend or introduce laws as a consequence of a judicial decision or a series of such decisions which they do not find in accordance with contemporary standards. But they should limit themselves to very general remarks and in no way suggest that the judges in particular cases have made wrong decisions. As a matter of fact, the rulings may be fully in accordance with the applicable law. The responsibility then rests with the legislator.

Politicians must also be extremely cautious when they publicly discuss the terms and conditions under which judges are employed. It is highly inappropriate, for example, to respond to the outcome of a particular case by suggesting that security of tenure of judges should be abolished and that judges should be fired when they make the "wrong" decision. 
This is not to say that arrangements like the extent of security of tenure of judges cannot be discussed by politicians as long as the rules eventually adopted satisfy the requirement of ensuring the independence and impartiality of the judiciary. It is a different matter that parliaments must exercise oversight over the executive branch, including the judiciary, to ensure the due administration of justice. The exercise of this duty is not an interference with the independence of judges.

\subsection{Courts Must Be Accessible}

It is important that courts are accessible. People must not refrain from taking their case to court because this is excessively expensive, troublesome or complicated. Access to justice is an important element in a society under the rule of law. This means, first of all, that criteria for admitting a case to be heard and decided in a court of law must not be too tough and strict. Some restrictions are inevitable, for too many cases will overload and impair the judicial system. But any restrictions must serve a justified objective and be necessary to achieve that objective. (Wallenberg Institute of Human Rights and Humanitarian Law and the Hague Institute for the Internationalization of Law, 2012) In this regard under Article 6 of the European Convention of Human Rights, people do have a right to free legal aid in criminal cases.

\subsection{Procedures Must Be Fair}

Furthermore, the adjudication procedures in courts of law must be fair. This means, among other things, that hearings in principle are open to the public. It also means that the parties can seek legal representation, that they have adequate time to prepare their arguments, that they are able to respond to the arguments of the other party or parties and that they are entitled to have their case reviewed by a superior judicial body.

\subsection{Qualifications, Selection and Training of Judicial Member}

Qualifications, selection and training of judicial member must be adapted with the lessons of the rule of law which are reflected in the next part of this essay under the rule of law's indicators.

\section{Human Rights Indicator of Rule of Law Related to Judiciary}

The effective and independent judiciary is one of the general and substantive indicators of rule of law and also its basis. In this section some of the indicators are investigated which are related to the human rights function of the judiciary power and generally those are introduced by the rule of law as guidelines for judiciary and criminal justice systems and especially for judges and prosecutors (United Nations, 1997).

\subsection{Judiciary's Respect for the Rights of Defendants and Victims}

International Covenant on Civil and Political Right, in particular art. 14. Provided that:

1) All persons shall be equal before the courts and tribunals. In the determination of any criminal charge against him, or of his rights and obligations in a suit at law, everyone shall be entitled to a fair and public hearing by a competent, independent and impartial tribunal established by law. The press and the public may be excluded from all or part of a trial for reasons of morals, public order or national security in a democratic society, or when the interest of the private lives of the parties so requires, or to the extent strictly necessary in the opinion of the court in special circumstances where publicity would prejudice the interests of justice; but any judgment rendered in a criminal case or in a suit at law shall be made public except where the interest of juvenile persons otherwise requires or the proceedings concern matrimonial disputes or the guardianship of children.

2) Everyone charged with a criminal offence shall have the right to be presumed innocent until proved guilty according to law.

3) In the determination of any criminal charge against him, everyone shall be entitled to the following minimum guarantees, in full equality:

(a) To be informed promptly and in detail in a language which he understands of the nature and cause of the charge against him;

(b) To have adequate time and facilities for the preparation of his defence and to communicate with counsel of his own choosing;

(c) To be tried without undue delay;

(d) To be tried in his presence, and to defend himself in person or through legal assistance of his own choosing; to be informed, if he does not have legal assistance, of this right; and to have legal assistance assigned to him, in any case where the interests of justice so require, and without payment by him in any such case if he does not have sufficient means to pay for it; 
(e) To examine, or have examined, the witnesses against him and to obtain the attendance and examination of witnesses on his behalf under the same conditions as witnesses against him;

(f) To have the free assistance of an interpreter if he cannot understand or speak the language used in court;

(g) Not to be compelled to testify against himself or to confess guilt.

4) In the case of juvenile persons, the procedure shall be such as to take account of their age and the desirability of promoting their rehabilitation.

5) Everyone convicted of a crime shall have the right to his conviction and sentence being reviewed by a higher tribunal according to law.

6) When a person has by a final decision been convicted of a criminal offence and when subsequently his conviction has been reversed or he has been pardoned on the ground that a new or newly discovered fact shows conclusively that there has been a miscarriage of justice, the person who has suffered punishment as a result of such conviction shall be compensated according to law, unless it is proved that the non-disclosure of the unknown fact in time is wholly or partly attributable to him.

7) No one shall be liable to be tried or punished again for an offence for which he has already been finally convicted or acquitted in accordance with the law and penal procedure of each country.

Also Declaration of Basic Principles of Justice for Victims of Crime and Abuse of Power, 1 in particular under the section of "Access to justice and fair treatment" principles 4, 5 and 6 provided as follows:

4) Victims should be treated with compassion and respect for their dignity. They are entitled to access to the mechanisms of justice and to prompt redress, as provided for by national legislation, for the harm that they have suffered.

5) Judicial and administrative mechanisms should be established and strengthened where necessary to enable victims to obtain redress through formal or informal procedures that are expeditious, fair, inexpensive and accessible. Victims should be informed of their rights in seeking redress through such mechanisms.

6) The responsiveness of judicial and administrative processes to the needs of victims should be facilitated by:

(a) Informing victims of their role and the scope, timing and progress of the proceedings and of the disposition of their cases, especially where serious crimes are involved and where they have requested such information;

(b) Allowing the views and concerns of victims to be presented and considered at appropriate stages of the proceedings where their personal interests are affected, without prejudice to the accused and consistent with the relevant national criminal justice system;

(c) Providing proper assistance to victims throughout the legal process;

(d) Taking measures to minimize inconvenience to victims, protect their privacy, when necessary, and ensure their safety, as well as that of their families and witnesses on their behalf, from intimidation and retaliation;

(e) Avoiding unnecessary delay in the disposition of cases and the execution of orders or decrees granting awards to victims (Ibid).

\subsection{Impartiality of the Courts}

International Covenant on Civil and Political Rights: Article14, para. 1: "All persons shall be equal before the courts and tribunals. In the determination of any criminal charge against him, or of his rights and obligations in a suit at law, everyone shall be entitled to a fair and public hearing by a competent, independent and impartial tribunal established by law"...

Article 2 Para. 1: "Each State Party to the present Covenant undertakes to respect and to ensure to all individuals within its territory and subject to its jurisdiction the rights recognized in the present Covenant, without distinction of any kind, such as race, colour, sex, language, religion ,political or other opinion, national or social origin, property, birth or other status" (Dowrkin, 1995).

\subsection{Protection of the Rights of Defendants and Victims}

International Covenant on Civil and Political Rights and also a Declaration of Basic Principles of Justice for Victims of Crime and Abuse of Power involved some issues about protection of the rights of defendants and victims. These rights are reflected in regional and international instruments of human rights.

1. Declaration of Basic Principles of Justice for Victims of Crime and Abuse of Power (General Assembly resolution 40/34, annex) (A/RES/40/34) 29 November 1985. 96th plenary meeting 


\subsection{Access to Redress for Miscarriage of Justice}

The provision of article 14 para, 6 of the International Covenant on Civil and Political Rights which aforementioned is about this matter.

\subsection{Response to Gender - Based Violence}

Declaration on the Elimination of Violence against Women, in art. 1 provided that "For the purposes of this Declaration, the term 'violence against women' means any act of gender based violence that results in, or is likely to result in, physical, sexual or psychological harm or suffering to women, including threats of such acts, coercion or arbitrary deprivation of liberty, whether occurring in public or in private life." And also Model Strategies and Practical Measures on the Elimination of Violence against Women in the Field of Crime Prevention and Criminal Justice involved some provisions in this ground.

\subsection{Children in Pre - Sentence Detention United Nations Standard}

Minimum Rules for the Administration of Juvenile Justice that as known as the Beijing Rules in Rule 13.1 states that "Detention pending trial shall be used only as a measure of last resort and for the shortest possible period of time." and in Rule 13.2 declared that "Whenever possible, detention pending trial shall be replaced by alternative measures, such as close supervision, intensive care or placement with a family or in an educational setting or home." Also in Rule 20.1 provided that "Each case shall from the outset be handled expeditiously, without any unnecessary delay."

United Nations Standard Minimum Rules for Non-custodial Measures which called The Tokyo Rules in Rule 6.1 provided that "Pretrial detention shall be used as a means of last resort in criminal proceedings, with due regard for the investigation of the alleged offence and for the protection of society and the victim."

\subsection{Independence of Judiciary - Tenure}

Principle 12 of the Basic Principles on the Independence of the Judiciary provided that "Judges, whether appointed or elected, shall have guaranteed tenure until a mandatory retirement age or the expiry of their term of office, where such exist."

Para. 3 of article 8 of the Universal Charter of the Judge which established by the International Association of Judges (Union International des Magistrates) ${ }^{2}$ under the part of "Security of office" provided that a judge must be appointed for life or for such other period and conditions, that the judicial independence is not endangered (Ibid).

\subsection{Independence of Judiciary - Discipline}

Principle 17 of the Basic Principles on the Independence of the Judiciary states that "a charge or complaint made against a judge in his/her judicial and professional capacity shall be processed expeditiously and fairly under an appropriate procedure. The judge shall have the right to a fair hearing. The examination of the matter at its initial stage shall be kept confidential, unless otherwise requested by the judge." And also in principle 18 provided that "Judges shall be subject to suspension or removal only for reasons of incapacity or behavior that renders them unfit to discharge their duties." As well as in principle 19 declared that "All disciplinary, suspensive or removal proceedings shall be determined in accordance with established standards of judicial conduct."

The Universal Charter of the Judge in article 10 under the "Civil and penal responsibility" provided that "Civil action, in countries where this is permissible, and criminal action, including arrest, against a judge must only be allowed un- der circumstances ensuring that his or her independence cannot be influenced." And also in article 11 in para. 3 under the "Administration and disciplinary action" provided that "Disciplinary action against a judge can only be taken when provided for by pre-existing law and in compliance with predetermined rules of procedures."

\subsection{Public Perception of Judicial Independence}

The Basic Principles on the Independence of the Judiciary in principle 1 acclaimed that "the independence of the judiciary shall be guaranteed by the State and enshrined in the Constitution or the law of the country. It is the duty of all governmental and other institutions to respect and observe the independence of the judiciary." As well as in principle 2 provided that "The judiciary shall decide matters before them impartially, on the basis of facts and in accordance with the law, without any restrictions, improper influences, inducements, pressures, threats or interferences, direct or indirect, from any quarter or for any reason."

\footnotetext{
${ }^{2}$ available at: www.iaj-uim.org
} 
Principle 4 of this document declared that "There shall not be any inappropriate or unwarranted interference with the judicial process, nor shall judicial decisions by the courts be subject to revision. This principle is without prejudice to judicial review or to mitigation or commutation by competent authorities of sentences imposed by the judiciary, in accordance with the law."

\subsection{Bribes to Judges, Prosecutors or Court Personnel}

Bangalore Principles of Judicial Conduct in paragraph 4.14 declared that "a judge and members of the judge's family, shall neither ask for, nor accept any gift, bequest and loan or favor in relation to anything done or to be done or omitted to be done by the judge in connection with the performance of judicial duties." And also in paragraph 4.15 acclaimed that "a judge shall not knowingly permit court staff or others subject to the judge's influence, direction or authority, to ask for, or accept, any gift, bequest, loan or favor in relation to anything done or to be done or omitted to be done in connection with his or her duties or functions."

\subsection{Judicial Misconduct}

Principle 17 of the Basic Principles on the Independence of the Judiciary in this regard provided that "a charge or complaint made against a judge in his/her judicial and professional capacity shall be processed expeditiously and fairly under an appropriate procedure. The judge shall have the right to a fair hearing. The examination of the matter at its initial stage shall be kept confidential, unless otherwise requested by the judge."

Principle 18 of these principles declared that "Judges shall be subject to suspension or removal only for reasons of incapacity or behavior that renders them unfit to discharge their duties." And also principle 19 provided that "All disciplinary, suspension or removal proceedings shall be determined in accordance with established standards of judicial conduct" (Larkins, 1996).

\subsection{Prosecutorial Misconduct}

Guidelines on the Role of Prosecutors ${ }^{3}$ which adopted by the eighth United Nations Congress on the prevention of crime and the treatment of offenders, Havana, 1990 in Guideline 21 provided that "Disciplinary offences of prosecutors shall be based on law or lawful regulations. Complaints against prosecutors which allege that they acted in a manner clearly out of the range of professional standards shall be processed expeditiously and fairly under appropriate procedures. Prosecutors shall have the right to a fair hearing. The decision shall be subject to independent review." In this regard, in Guideline 22 declared that "Disciplinary proceedings against prosecutors shall guarantee an objective evaluation and decision. They shall be determined in accordance with the law, the code of professional conduct and other established standards and ethics and in the light of the present Guidelines."

\subsection{Publically Available Reports on Court Spending}

Under the "Public reporting" in article 10 of the United Nations Convention against Corruption must be "Taking into account the need to combat corruption, each State Party shall, in accordance with the fundamental principles of its domestic law, take such measures as may be necessary to enhance transparency in its public administration, including with regard to its organization, functioning and decision-making processes, where appropriate. Such measures may include, inter alia:

(a) adopting procedures or regulations allowing members of the general public to obtain, where appropriate, information on the organization, functioning and decision making processes of its public administration and, with due regard for the protection of privacy and personal data, on decisions and legal acts that concern members of the public; (b) simplifying administrative procedures, where appropriate, in order to facilitate public access to the competent decision-making authorities; and (c) publishing information, which may include periodic reports on the risks of corruption in its public administration."

\subsection{Equal Application of the Law by Judges}

In according with the principle 2.1 of Bangalore principles of judicial conduct "a judge shall perform his or her judicial duties without favor, bias or prejudice." International Code of Conduct for Public Officials also in para. 3 provided that "Public officials shall be attentive, fair and impartial in the performance of their functions and, in particular, in their relations with the public. They shall at no time afford any undue preferential treatment to any group or individual, or improperly discriminate against any group or individual, or otherwise abuse the power and authority vested in them" (Ibid).

\footnotetext{
${ }^{3}$. Guidelines on the Role of Prosecutors adopted by the eighth United Nations congress on the Prevention of Crime and the Treatment of Offenders, Havana, Cuba, 27 August to 7 September 1990
} 


\subsection{Treatment of Children by the Courts}

Article 40 of the Convention on the Rights of the Child, provided that:

"1. States Parties recognize the right of every child alleged as, accused of, or recognized as having infringed the penal law to be treated in a manner consistent with the promotion of the child's sense of dignity and worth, which reinforces the child's respect for the human rights and fundamental freedoms of others and which takes into account the child's age and the desirability of promoting the child's reintegration and the child's assuming a constructive role in society.

"2. To this end, and having regard to the relevant provisions of international instruments, States Parties shall, in particular, ensure that:

"(a) No child shall be alleged as, be accused of, or recognized as having infringed the penal law by reason of acts or omissions that were not prohibited by national or international law at the time they were committed;

“(b) Every child alleged as or accused of having infringed the penal law has at least the following guarantees:

“(i) To be presumed innocent until proven guilty according to law;

“(ii) To be informed promptly and directly of the charges against him or her, and, if appropriate, through his or her parents or legal guardians, and to have legal or other appropriate assistance in the preparation and presentation of his or her defence;

"(iii) To have the matter determined without delay by a competent, independent and impartial authority or judicial body in a fair hearing, according to law, in the presence of legal or other appropriate assistance and, unless it is considered not to be in the best interest of the child, in particular, taking into account his or her age or situation, his or her parents or legal guardians;

"(iv) Not to be compelled to give testimony or to confess guilt; to examine or have examined adverse witnesses and to obtain the participation and examination of witnesses on his or her behalf under conditions of equality;

"(v) If considered to have infringed the penal law, to have this decision and any measures imposed in consequence thereof reviewed by a higher competent, independent and impartial authority or judicial body according to law;

"(vi) To have the free assistance of an interpreter if the child cannot understand or speak the language used;

"(vii) To have his or her privacy fully respected at all stages of the proceedings.

"3. States Parties shall seek to promote the establishment of laws, procedures, authorities and institutions specifically applicable to children alleged as, accused of, or recognized as having infringed the penal law, and, in particular:

"(a) The establishment of a minimum age below which children shall be presumed not to have the capacity to infringe the penal law;

“(b) Whenever appropriate and desirable, measures for dealing with such children without resorting to judicial proceedings, providing that human rights and legal safeguards are fully respected.

"4. A variety of dispositions, such as care, guidance and supervision orders; counselling; probation; foster care; education and vocational training programmes and other alternatives to institutional care shall be available to ensure that children are dealt with in a manner appropriate to their well-being and proportionate both to their circumstances and the offence."

Committee on the Rights of the Child, in Forty-fourth session Geneva, 15 January-2 February 2007 adopted the general comment No. 10 (2007) about Children's rights in the juvenile justice and under the title of "Best interests of the child (art. 3)" in comment 10 enounced that in all decisions taken within the context of the administration of juvenile justice, the best interests of the child should be a primary consideration. Children differ from adults in their physical and psychological development, and their emotional and educational needs. Such differences constitute the basis for the lesser culpability of children in conflict with the law. These and other differences are the reasons for a separate juvenile justice system and require a different treatment for children. The protection of the best interests of the child means, for instance, that the traditional objectives of criminal justice, such as repression/retribution, must give way to rehabilitation and restorative justice objectives in dealing with child offenders. This can be done in concert with attention to effective public safety. 
Also United Nations Standard Minimum Rules for the Administration of Juvenile Justice, which is known as The Beijing Rules in Rule 14.1 provided that "Where the case of a juvenile offender has not been diverted (under rule 11), she or he shall be dealt with by the competent authority (court, tribunal, board, council, etc.) according to the principles of a fair and just trial." And as well as in Rule 14.2 stated that "The proceedings shall be conducive to the best interests of the juvenile and shall be conducted in an atmosphere of understanding, which shall allow the juvenile to participate therein and to express herself or himself freely" (Roland, 2007).

\subsection{Legal Assistance for Children in Conflict with the Law}

Convention on the Rights of the Child, in art. 40 enounced that:

"1. States Parties recognize the right of every child alleged as, accused of, or recognized as having infringed the penal law to be treated in a manner consistent with the promotion of the child's sense of dignity and worth, which reinforces the child's respect for the human rights and fundamental freedoms of others and which takes into account the child's age and the desirability of promoting the child's reintegration and the child's assuming a constructive role in society.

" 2 . To this end, and having regard to the relevant provisions of international instruments, States Parties shall, in particular, ensure that:

“...

"(b) Every child alleged as or accused of having infringed the penal law has at least the following guarantees:

“...

"(ii) To be informed promptly and directly of the charges against him or her, and, if appropriate, through his or her parents or legal guardians, and to have legal or other appropriate assistance in the preparation and presentation of his or her defence;

“..."

This convention in art. 37 involved same provisions as follow:

(d): "Every child deprived of his or her liberty shall have the right to prompt access to legal and other appropriate assistance, as well as the right to challenge the legality of the deprivation of his or her liberty before a court or other competent, independent and impartial authority, and to a prompt decision on any such action" (Woolley, 2014).

\subsection{Special Procedures for Child Victims and Witnesses of Crime}

Article 8 of the Guidelines on Justice in Matters involving Child Victims and Witnesses of Crime, ensure that "As stated in international instruments and in particular the Convention on the Rights of the Child as reflected in the work of the Committee on the Rights of the Child, and in order to ensure justice for child victims and witnesses of crime, professionals and others responsible for the well-being of those children must respect the following cross-cutting principles:

“(a) Dignity. Every child is a unique and valuable human being and as such his or her individual dignity, special needs, interests and privacy should be respected and protected;

"(b) Non-discrimination. Every child has the right to be treated fairly and equally, regardless of his or her or the parent's or legal guardian's race, ethnicity, color, gender, language, religion, political or other opinion, national, ethnic or social origin, property, disability and birth or other status;

"(c) Best interests of the child. While the rights of accused and convicted offenders should be safeguarded, every child has the right to have his or her best interests given primary consideration. This includes the right to protection and to a chance for harmonious development:

"(i) Protection. Every child has the right to life and survival and to be shielded from any form of hardship, abuse or neglect, including physical, psychological, mental and emotional abuse and neglect;

"(ii) Harmonious development. Every child has the right to a chance for the harmonious development and to a standard of living adequate for physical, mental, spiritual, moral and social growth. In the case of a child who has been traumatized, every step should be taken to enable the child to enjoy healthy development;

"(d) Right of participation. Every child has, subject to national procedural law, the right to express his or her views, opinions and beliefs freely, in his or her own words, and to contribute especially to the decisions affecting his or her life, including those taken in any judicial processes, and to have those views taken into 
consideration according to his or her abilities, age, intellectual maturity and evolving capacity" (Hayek, 1993).

\subsection{Detention of Children Only as a Last Resort}

Convention on the Rights of the Child, art. 37 (b) provided that "States Parties shall ensure that:... the arrest, detention or imprisonment of a child shall be in conformity with the law and shall be used only as a measure of last resort and for the shortest appropriate period of time." And also the United Nations Rules for the Protection of Juveniles Deprived of their Liberty, in para. 2 enounced that "Juveniles should only be deprived of their liberty in accordance with the principles and procedures set forth in these Rules and in The Beijing Rules. Deprivation of the liberty of a juvenile should be a disposition of last resort and for the minimum necessary period and should be limited to exceptional cases. The length of the sanction should be determined by the judicial authority, without precluding the possibility of his or her early release."

In this regard the United Nations Standard Minimum Rules for the Administration of Juvenile Justice (The Beijing Rules) in Rule 13.1 provided that "Detention pending trial shall be used only as a measure of last resort and for the shortest possible period of time." And as well as in Rule 13.2 enounced that "Whenever possible, detention pending trial shall be replaced by alternative measures, such as close supervision, intensive care or placement with a family or in an educational setting or home." And also Rule 19.1 provided "The placement of a juvenile in an institution shall always be a disposition of last resort and for the minimum necessary period" (Ibid).

\subsection{Competence (Skills and Knowledge) of Prosecutors}

Guidelines on the Role of Prosecutors in guideline 1 declared that "Persons selected as prosecutors shall be individuals of integrity and ability, with appropriate training and qualifications." And guideline 2 (b) provided that "States shall ensure that:... prosecutors have appropriate education and training and should be made aware of the ideals and ethical duties of their office, of the constitutional and statutory protections for the rights of the suspect and the victim, and of human rights and fundamental freedoms recognized by national and international law."

\subsection{Competence (Skills and Knowledge) of Judges}

The Basic Principles on the Independence of the Judiciary in principle 10 enounced that "Persons selected for judicial office shall be individuals of integrity and ability with appropriate training or qualifications in law. Any method of judicial selection shall safeguard against judicial appointments for improper motives. In the selection of judges, there shall be no discrimination against a person on the grounds of race, color, sex, religion, political or other opinion, national or social origin, property, birth or status, except that a requirement, that a candidate for judicial office must be a national of the country concerned, shall not be considered discriminatory."

\subsection{Competence (Skills and Knowledge) of Defence Counsels}

Principle 9 of Basic Principles on the Role of Lawyers, provided that "Governments, professional associations of lawyers and educational institutions shall ensure that lawyers have appropriate education and training and be made aware of the ideals and ethical duties of the lawyer and of human rights and fundamental freedoms recognized by national and international law."

\subsection{Remuneration of Judges}

The Universal Charter of the Judge in art. 13 enounced that "The judge must receive sufficient remuneration to secure true economic independence. The remuneration must not depend on the results of the judge's work and must not be reduced during his or her judicial service."

\subsection{Remuneration of Prosecutors}

Guidelines on the Role of Prosecutors, guideline 6 in this regard declared that "Reasonable conditions of service of prosecutors, adequate remuneration and, where applicable, tenure, pension and age of retirement shall be set out by law or published rules or regulations."

Standards of Professional Responsibility and Statement of the Essential Duties and Rights of Prosecutors in section 6 under the title of Empowerment enounced that "In order to ensure that prosecutors are able to carry out their professional responsibilities independently and in accordance with these standards, prosecutors should be protected against arbitrary action by governments. In general, they should be entitled:... (c) To reasonable conditions of service and adequate remuneration, commensurate with the crucial role performed by them and not to have their salaries or other benefits arbitrarily diminished." 


\subsection{Salaries or Fees of Publicly Funded Defence Counsels Are Paid on Time}

The Basic Principles on the Role of Lawyers, principle about this matter declared that "Governments shall ensure the provision of sufficient funding and other resources for legal services to the poor and, as necessary, to other disadvantaged persons. Professional associations of lawyers shall cooperate in the organization and provision of services, facilities and other resources" (Woolley, 2014).

\section{Conclusion}

Rule of law is a concept with substantive and formal dimensions and different attitudes. Despite of its controversial nature, recently, it is accepted by every legal system and gained universal acceptance.

The rule of law had diverse elements which, despite of differences in the principles and content of formal and substantive conceptions of rule of law, they are generally on the same ground in regard to equality before the law and adherence to it, limitation of authorities of state officials and governmental institutions, impartiality and independence of the judicial system, the supremacy of law, separation of powers and other similar issues.

This concept has a broad sense and it intervenes in social, political, legal, citizenship, environmental and governance fields. It has own guidelines and measures all of these areas. These guidelines and indicators are not same in every field, but all of them adherence of the common basis and foundations. Judiciary in each state is one of these areas which rule of law is based on it such as separation powers principle and independence judiciary from other powers and authorities. Finally, this matter led to impartiality and independence of the judiciary as a result of enforcing the rule of law. Thus, judicial independence is a base of rule of law as well as its outcome and consequence.

In order to achieve this result, some guidelines, instructions and indicators are provided by the rule of law principle to enforce in a judiciary that caused to establish independence and impartiality in judicial systems. As a result, under this situation, fundamental liberties and human rights are protected and promoted.

Measures, guidelines and indicators of rule of law related to the judiciary are provided and offered for every sector in judiciary power, including protection of the rights of defendants and victims, the impartiality of the courts, judicial and prosecutorial misconduct, children's rights related to the courts and detention center, skill and knowledge of judges and prosecutors and etc. Generally it involves personal and institutional indicators and guidelines from skill and educational measures for judicial members and personnel to conducts and behaviors of each person, authority or institution related to the judiciary. Indeed enforcing these guidelines led to judicial independence and subsequently protection and promotion of human rights.

\section{References}

Bangalore Principles of Judicial Conduct.

Basic Principles on the Independence of the Judiciary.

Basic Principles on the Use of Force and Firearms by Law Enforcement Officials.

Beetham, D. (2004). Freedom as the foundation. Journal of Democracy, 15(4), 62-63.

Body of Principles for the Protection of All Persons under Any Form of Detention or Imprisonment.

Code of Conduct for Law Enforcement Officials.

Cole, M. (2011). Rule of Law Handbook, A Practitioner's Guide for Judge Advocate. The Judge Advocate General's Legal Center and School, U.S. Army \& Center for Law and Military Operations. Charlottesville, Virginia.

Convention against Torture and Other Cruel, Inhuman or Degrading Treatment or Punishment - CAT (1984/1987).

Convention on the Elimination of All Forms of Discrimination against Women - CEDAW (1979/1981).

Convention on the Elimination of All Forms of Discrimination against Women.

Convention on the Elimination of All Forms of Racial Discrimination.

Convention on the Protection of the Rights of All Migrant Workers and Members of Their Families.

Convention on the Rights of Persons with Disabilities - CRPD (2006/2008).

Convention on the Rights of Persons with Disabilities.

Convention on the Rights of the Child - CRC (1989/1990). 
Convention on the Rights of the Child and Guide lines on Justice in Matters involving Child Victims and Witnesses of Crime.

Convention on the Rights of the Child.

Declaration of Basic Principles of Justice for Victims of Crime and Abuse of Power.

Declaration on the Elimination of Violence against Women.

Declaration on the Protection of All Persons from Being Subjected to Torture and Other Cruel, Inhuman or Degrading Treatment or Punishment.

Dworkin, R. A. (1995). Matter of principle. Cambridge, Harvard University Press.

Guidelines for the Effective Implementation of the Code of Conduct for Law Enforcement Officials.

Hayek, F. A. (1993). The constitution of liberty. London, Roultledge.

International Code of Conduct for Public Officials.

International Convention for the Protection of All Persons from Enforced Disappearance (2006/2010).

International Convention for the Protection of All Persons from Enforced Disappearance.

International Convention on the Protection of the Rights of All Migrant Workers and Members of Their Families - CMW (1990/2003).

Larkins, C. M. (1996). Judicial independence and democratization: A theoretical and conceptual analysis, In Zareii, M, H. (Trans), Aftab Journal, 15.

Markaz Malmiri, A. (2007). Rule of law: Concepts, basics and perceptions, Office of Legal Studies in Research Center of The Islamic Consultative Assembly.

Model Strategies and Practical Measures on the Elimination of Violence against Women in the Field of Crime Prevention and Criminal Justice.

Model Strategies and Practical Measures on the Elimination of Violence against Women in the Field of Crime Prevention and Criminal Justice.

Montesquieu, Ch. (1748). Spirit of laws, Mehtadi, A, A (Trans), Amir Kabir Press, Tehran, Iran.

Peerenboom, R. (2005). Human rights and rule of law: What's the relationship? Georgetown Journal of International Law. UCLA School of Law Research Paper, 36, 05-31.

Principles for the protection and promotion of human rights through action to combat impunity.

Rasekh, M. (2006). Theory of right and international human rights, Journal of Legal researches, Tehran University, Iran, 41.

Raz, J. (1977). The rule of law and its virtue. The Law Quarterly Review, 93, 195-211.

Roland, N. (2007). Legal anthropology, In NikPai, a (Trans), Jangal Press, Tehran, Iran.

Rostam Nejad, H., \& Rahim Khoi, E. (2012). Principle of rule of law in international human rights, Kelk-e-Saba Press, Tehran.

Security Council 21/26.

Security Council 22/13.

Security Council A/HRC/22/59.

Standard Minimum Rules for the Treatment of Prisoners.

Strengthening of the Rule of Law, Report of the Secretary-General, Doc. A/ 59/402 of 1 October 2004.

The first Special Rapporteur on the promotion of truth, justice, reparation and guarantees of non-recurrence was appointed in May 2012. In his first report to the General Assembly) A/67/368), he highlighted the ways in which the promotion of truth, justice, reparation and guarantees of non-recurrence contributes to strengthening the rule of law.

The Universal Charter of the Judge (of the International Association of Judges.

Tremblay, L. B. (1997). The Rule of Law, Justice and Interpretation. London, McGill - Queen's University Press.

$\mathrm{UN}$, Report of the Secretary-General on the rule of law and transitional justice in conflict and post-conflict societies $(\mathrm{S} / 2004 / 616)$. 
United Nations Conference on Sustainable Development.

United Nations Convention against Corruption.

United Nations General Assembly. Resolution adopted by the General Assembly. A/RES/67/1. Declaration of the High-level Meeting of the General Assembly on the Rule of Law at the National and International Levels. 2008.

United Nations General Assembly. Sixty-eighth session. Item 85 of the provisional agenda. The rule of law at the national and international levels. Strengthening and coordinating United Nations rule of law activities. A/68/213. 29 July 2013.

United Nations Guidelines for the Prevention of Juvenile Delinquency (The Riyadh Guidelines).

United Nations Rules for the Protection of Juveniles Deprived of their Liberty.

United Nations Standard Minimum Rules for Non-custodial Measures (The Tokyo Rules).

United Nations Standard Minimum Rules for the Administration of Juvenile Justice (The Beijing Rules).

United Nations, Committee on the Rights of the Child, Forty-Fourth Session, Geneva, 15 January-2 February 2007 General Comment No. 10 (2007), Children's Rights in Juvenile Justice, CRC/C/GC/10. 25 April 2007.

United Nations, Compendium of United Nations standards and norms in crime prevention and criminal justice (New York: United Nations, 2006). Available at: www.unodc.org/pdf/compendium/compendium_2006.pdf

United Nations. (2011). Rule of Law Indicators, Implementation Guide and Project Tools. United Nations publication.

United Nations. "Basic Principles on the Independence of the Judiciary", Adopted by the Seventh United Nations Congress on the Prevention of Crime and the Treatment of Offenders held at Milan from 26 August to 6 September 1985 and endorsed by General Assembly resolution 40/32 of 29 November 1985 and 40/146 of 13 December 1985.

United Nations. A/RES/48/132.

United Nations. Basic Principles on the Independence of the Judiciary, Adopted by the Seventh United Nations Congress on the Prevention of Crime and the Treatment of Offenders held at Milan from 26 August to 6 September 1985 and endored by General Assembly resolusion 40/32 of 29 November 1985 and 40/146 of 13 December 1985.

Woolley, A. (2014). The Lawyer as Advisor and the Practice of the Rule of Law. 47 UBC Law Review. Electronic copy. Retrieved from http://ssrn.com/abstract=2450599

\section{Copyrights}

Copyright for this article is retained by the author(s), with first publication rights granted to the journal.

This is an open-access article distributed under the terms and conditions of the Creative Commons Attribution license (http://creativecommons.org/licenses/by/4.0/). 